\title{
Cracking the Microbial Cell Wall
}

\author{
Amro Abd Al Fattah Amara* \\ *Department of the Protein Research, Genetic Engineering and Biotechnology Research Institute, and the head of the \\ office of the Scientific Publishing, City for Scientific Research and Technological Applications, Universities and Research \\ Center district, New Borg El-Arab, Egypt
}

Received: : 17 March, 2017; Accepted: 15 April, 2017; Published: 25 April, 2017

*Corresponding authors: Amro Abd Al Fattah Amara, City for Scientific Research and Technological Applications, Universities and Research Center District, New Borg El-Arab, P.O. Box: 21934 Alex, Egypt, Tel No: +203-4593422; Fax: +203-4593497; E-mail: amroamara@web.de or amroamara@protonmail.ch

\section{Dear Editor}

The Sponge like Protocol was recently published by Amara et al. (2013) [1]. The protocol describes a new method for bacterial evacuation from their cytoplasmic contents without deforming their 3D structure or their surface antigens [1,2]. The protocol was originally optimized by Plackett-Burman design $[1,3]$. It based on randomising both of the +1 which was the minimum inhibition concentration MIC and the minimum growth concentration MGC (-1) of compounds able to induce pores in bacterial cell walls $[1,3]$. The used chemical compounds are SDS, $\mathrm{NaOH}, \mathrm{H}_{2} \mathrm{O}_{2}, \mathrm{CaCO}_{3}$ and the $\mathrm{NaCl}$ and the Ethanol were used during the evacuation processes. By determining each of the MIC and MGC and running either the full Plackett-Burman twelve experimental design as in the original protocol or running the best two experiments which giving the best results as in the reduced protocol, that guarantee full evacuation with nearly no effect on the 3D or the surface antigens $[4,2]$.

Using such simple protocol with the virus new castle and with the Eukaryotic Saccharomyces cerevisiae the protocol success to turn them to ghosts $[5,6,7]$. The same concept but by using the MIA and MGA of the lysozyme and Proteinase K with Bacillus stearothermophilius it is successfully turned to ghost [8]. After examining the protocol with several microbial strains from each of the prokaryotic and the eukaryotic as well as the viruses and the spore former bacteria one could say that the microbial cell wall has been cracked [9-11]. Such protocol open many opportunities in preparing vaccines from microbes might show some hardness in the past. Such protocol is simple reliable in expensive but one could not say in house while microbes need some care particularly the pathogens.

\section{References}

1. Amara AA, Salem-Bekhit MM, Alanazi FK. Sponge-like: a new protocol for preparing bacterial ghosts. The Scientific World Journal 2013;2013:1-7. doi: 10.1155/2013/545741

2. Amara AA, Neama AJ, Hussein A, Hashish EA, Sheweita SA. Evaluation the surface antigen of the Salmonella typhimurium ATCC 14028 ghosts prepared by "SLRP". ScientificWorldJournal 2014;2014:840863. doi: $10.1155 / 2014 / 840863$
3. Amara AA, Salem-Bekhit MM, Alanazi FK. Plackett-Burman randomization method for Bacterial Ghosts preparation form E. coli JM109. Saudi Pharm J. 2014;22(3):273-279

4. Amara AA, Salem-Bekhit MM, Alanazi FK. Preparation of bacterial ghosts for E. coli JM109 using sponge-like reduced protocol. Asian J Biol Sci 2013;6(3):363-369

5. El-Baky NA, Amara AA. Newcastle disease virus (LaSota strain) as a model for virus Ghosts preparation using $\mathrm{H}_{2} \mathrm{O}_{2}$ bio-critical concentration. International Science and Investigation journal. 2014;3(5):38-50

6. Amara AA. Saccharomyces cerevisiae Ghosts Using the Sponge-Like ReReduced Protocol SOJ Biochem. 2015:1(1):1-4. doi: 10.15226/2376$4589 / 2 / 1 / 00107$

7. Amara AA. Bacterial and Yeast Ghosts: E. coli and Saccharomyces cerevisiae preparation as drug delivery model .ISIJ Biochemistry. 2015;4:11.

8. Amara AA. The critical activity for the cell all degrading enzymes: Could the use of the lysozyme for microbial ghosts preparation establish emergance oral vaccination protocol? . International Science and Invastigation Journal 2016;5(2):351-369

9. Amara AA. Kostenlos viral ghosts, bacterial ghosts microbial ghosts and more: Germany: Schuling Verlag; 2015.

10. Amara AA. Lysozymes, Proteinase K, Bacteriophage E Lysis Proteins, and some Compounds for MGs Preparation: a Review and Food for Thought. SOJ Biochem. 2016;2(1):1-16. doi: 10.15226/2376$4589 / 2 / 1 / 00108$

11. Amara AA. Vaccine against pathogens: A review and food for thought. SOJ Biochemistry. 2016;2(2):1-20. doi: 10.15226/2376$4589 / 2 / 2 / 00108$

DOI: DOI: http://dx.doi.org/10.15226/2473-2176/2/1/00116 